\title{
First occurrence of cubera snapper Lutjanus cyanopterus (Cuvier, 1828) in the southern Brazilian coast
}

\author{
Sanches, EG. ${ }^{a *}$, Costa, WM. ${ }^{b}$, Vilani, FG. ${ }^{b}$, Krueger, DM. ${ }^{b}$, Passini, G. $^{b}$ and Cerqueira, VR. ${ }^{b}$ \\ ${ }^{a}$ Instituto de Pesca, Agência Paulista de Tecnologia dos Agronegócios - APTA, \\ Secretaria de Agricultura e Abastecimento - SAA, Av. Cais do Porto, 2275, CEP 11680-000, Ubatuba, SP, Brazil \\ ${ }^{\mathrm{b}}$ Laboratório de Peixes Marinhos, Departamento de Aquicultura, Universidade Federal de Santa Catarina - UFSC, \\ Rod. Ademar Gonzaga, 1346, CEP 88040-900, Florianópolis, SC, Brazil \\ *e-mail: esanches@pesca.sp.gov.br
}

Received September 8, 2011 - Accepted January 24, 2012 - Distributed November 30, 2012

(With 2 figures)

\section{Introduction}

The Lutjanidae is a family composed of 17 genera and approximately 103 species of mostly reef-dwelling marine fishes collectively known as snappers. Within this family, 64 species compose the genus Lutjanus (Allen, 1985). It is considered a high-value fish on the market and according to Rezende et al. (2003), fish of the Lutjanidae family are highly vulnerable to overfishing because they have slow growth $(\mathrm{K}<1.5)$ and high longevity (20 to 30 years).

The cubera snapper Lutjanus cyanopterus (Cuvier, 1828) is the largest lutjanid species in the western Atlantic and may reach up to $57 \mathrm{~kg}$ in weight and $1600 \mathrm{~mm}$ in length (Allen, 1985). Cubera snapper is a carnivorous fish, and feeds primarily on fish and crabs. Their strong canines allow mature cubera to feed on large crustaceans including lobsters and crabs. Their feeding grounds are typically located near the bottom in rocky reef areas or adjacent to other structures. Cubera snapper is a subtropical species distributed across the western Atlantic, Nova Scotia in Canada and Bermuda, to the coast of São Paulo (Figueiredo and Menezes, 1980; Moura and Menezes, 2003; Moura and Lindeman, 2007). More recently, however, Claro and Lindeman (2008), restrict the geographic distribution of L. cyanopterus to the northeastern Brazilian coast (Bahia state, $\left.17^{\circ} \mathrm{S}\right)$.

On 17 March 2009, a specimen of cubera snapper (46,1 cm total length, LT, 1.456,3 g mass) (Figure 1) was caught in Lagoa da Conceição, Florianópolis, Santa Catarina, Brazil (27 $37^{\prime} \mathrm{S}$ and $48^{\circ} 27^{\prime} \mathrm{W}$; Figure 2$)$. The specimen was collected employing experimental fish traps on a rocky bottom, at $4 \mathrm{~m}$ depth. Bottom temperature and salinity were $22{ }^{\circ} \mathrm{C}$ and $27 \%$ o. Specimen identification was based on Figueiredo and Menezes (1980) and Claro and Lindeman (2008). Diagnostic Features: Body relatively elongate and slender. large mouth with thick lips; canine teeth on both jaws, strong and with an enlarged pair nearby the tip, visible when mouth is closed; vomerine tooth patch crescentic to triangular, without a medial posterior extension; preopercular margin with a weak knob; dorsal fin with 10 spines and 14 soft rays; anal fin rounded, with 3 spines and 7 soft rays; pectoral fins short, not reaching level of anus; with 16 to 18 rays; caudal fin nearly truncate. Scale rows on back rising obliquely above lateral line. Colour: back

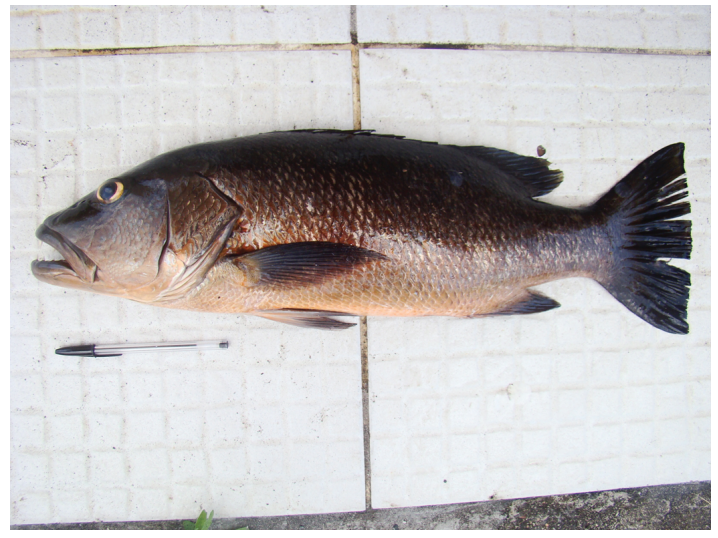

Figure 1. Specimen of Lutjanus cyanopterus collected in Florianópolis (Santa Catarina state, Brazil).

and sides pale to dark grey, with a reddish tinge; dorsal and caudal fins greyish; anal and pelvic fins reddish and pectoral fins translucent or greyish. The specimen was deposited in the collection of the Museum of Zoology of the University of São Paulo (MZUSP 110.263).

This snapper is slightly different than some of the others in the Lutjanidae family as it has an elongate, slender body that is not very deep (Moura and Lindeman, 2007). It is similar to other lutjanids in having a long pectoral fin, and a continuous dorsal fin. Smaller adults of the cubera snapper are difficult to distinguish from the common gray snapper, Lutjanus griseus. The relative shape of the vomerine tooth patch is typically cited as the sole reliable criterion (Claro and Lindeman, 2008).

The occurrence of L. cyanopterus on the coast of Santa Catarina, southern Brazil, observed in this study, shows that this species has a wider geographical distribution than has been previously published, expanding by $1000 \mathrm{~km}$ southward its geographical range.

L. cyanopterus is reef-associated, living inshore or nearshore, over rocky ledges and overhangs, but the young members of this species typically inhabit inshore mangrove areas and seagrass beds that offer protection from predators and are also known to enter estuaries, and tidal reaches 


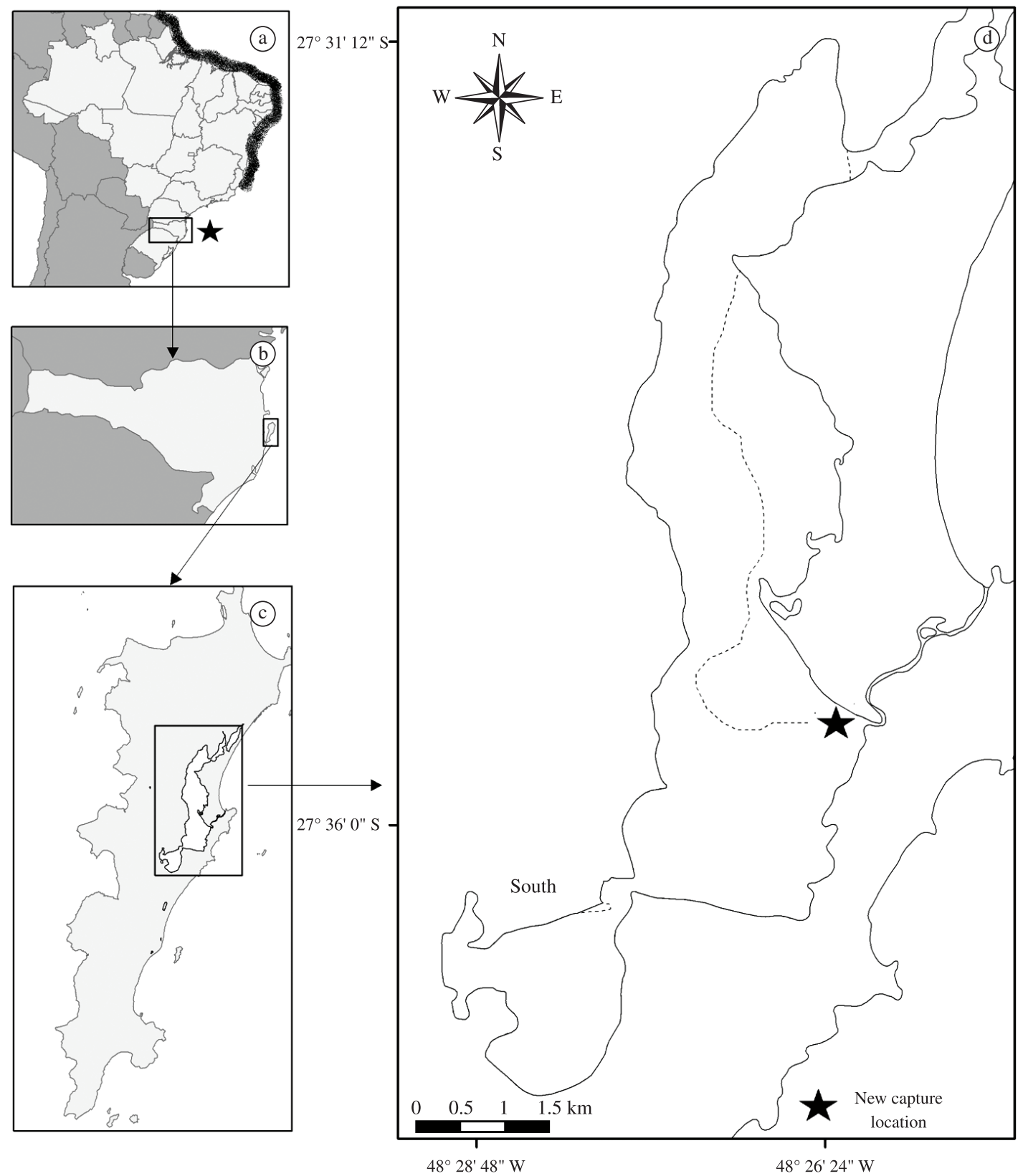

Figure 2. a) Distribution of Lutjanus cyanopterus in the south-west Atlantic (from Claro and Lindeman, 2008). b) State of Santa Catarina, Brazil. c) Lagoa da Conceição. d) New southern record ( $\star$ ).

of streams and freshwater canals. The cubera snapper is rare throughout its distributional range and currently classified as vulnerable by the International Union for Conservation of Nature and Natural Resources (IUCN, 2010). On the southeastern coast of Brazil, this species is even more threatened and categorized as "collapsed" in the Red List of Vertebrates of São Paulo (Bressan et al., 2009). This range extension of the species in Brazil is hopeful and, although this species has not been recorded from the Marine Biological Reserve Ilha do Arvoredo, in
Santa Catarina, it is possible that this species is present in this location, wherever the species may be relatively protected. More studies are necessary to assess information on population structure and conservation of this species in the southern Brazilian coast.

\section{References}

ALLEN, GR., 1985. Snappers of the World: An annotated and illustrated catalogue of lutjanid species known to date. Rome: FAO. 208 p. 
BRESSAN, PM., KIERULFF, MCM. and SUGIEDA, AM., 2009. Fauna ameaçada de extinção no Estado de São Paulo: vertebrados. São Paulo: Fundação Parque Zoológico de São Paulo; Secretaria do Meio Ambiente. 460 p.

CLARO, R. and LINDEMAN, KC., 2008. Biología y manejo de los pargos (Lutjanidae) en el Atlántico occidental. La Habana: Instituto de Oceanología, CITMA. 472 p.

FIGUEIREDO, JL. and MENEZES, NA., 1980. Manual de peixes marinhos do sudeste do Brasil. São Paulo: Museu de Zoologia, Universidade de São Paulo. vol. 3, 116 p.

International Union for Conservation of Nature - IUCN, 2010. IUCN Red List of Threatened Species. version 2010.1. Available from: <www.iucnredlist.org>. Access in: 15 jul. 2011.
MOURA, RL. and MENEZES, NA., 2003. Família Lutjanidae. In MENEZES, NA., BUCKUP, PA., FIGUEIREDO, JL. and MOURA, RL. (Eds.). Catálogo das espécies de peixes marinhos do Brasil. São Paulo: Museu de Zoologia da USP. p. 82-83.

MOURA, RL. and LINDEMAN, KC., 2007. A new species of snapper (Perciformes: Lutjanidae) from Brazil, with comments on the distribution of Lutjanus griseus and Lutjanus apodus. Zootaxa, vol. 1422, p. 31-43.

REZENDE, SM., FERREIRA, BP. and FRÉDOU, T., 2003. A pesca de lutjanídeos no nordeste do Brasil: histórico das pescarias, características das espécies e relevância para o manejo. Boletim Técnico Científico do CEPENE, vol. 11, p. 1-17. 
